\title{
The current status of environmental sustainability implementation during the design process in New Product Development
}

\author{
Emelia Delaneya, Wei Liua, \\ aKing's College London \\ *Corresponding author e-mail: wei.liu@kcl.ac.uk
}

\begin{abstract}
:
Environmental sustainability during New Product Development has been identified within in literature as being a key issue. The design process has been highlighted as having a great impact on the overall sustainability of a product and has been a rising theme for academic and industrial interest. Although there is an extensive range of literature identifying key methodologies, tools and factors of environmental sustainability to be implemented during the product design process, it is unclear of what is currently being implemented by product designers within industry. This study explores the themes of environmental sustainability and the design process through a literature review and semi-structured interviews to understand the current status of environmental sustainability during the product design process. From this study an initial conceptual framework has been developed to illustrate this. Future research directions have also been outlined.
\end{abstract}

Keywords: Product Design; Environmental Sustainability; Sustainability; Design Process; New Product Development

\section{Introduction}

Sustainability is a wide-ranging issue and the importance of implementing sustainability during the product design process during New Product Development (NPD) is increasingly being recognised by both academia and industry. Sustainability is most commonly defined as the "development that meets the needs of the present without compromising the ability of future generations to meet their own needs" (Brudtland et al., 1987, p. 16). Three pillars divide sustainability into social, environmental and economic needs (Clark et al., 2009), this study focuses on environmental sustainability. Product design is an industry which provides creative solutions to aid sustainability and is estimated to have up to $80 \%$ impact of the overall sustainability of a product during NPD (Ahmad et al., 2018; Waage, 2007; Yang and Song, 2006).

Previous literature has focused on Design for Sustainability (DfS) methodologies and identifying factors of sustainability highlighted to improve the overall sustainability during NPD. However, it remains unclear how industry currently integrates environmental sustainability into the design 
process. To address these gaps this study describes the results from 12 semi-structured interviews with product designers investigating the current status of environmental sustainability integration during NPD. This review has enabled the development of an initial conceptual framework illustrating the current status of environmental sustainability as well as offering suggestions for future research.

\section{Theoretical Background}

\subsection{Environmental Sustainability}

DfS are a range of methodologies to aid the integration of sustainability during the product design process; green design, eco-design, emotional durability, and cradle-to-cradle are all examples of DfS methodologies (Ceschin and Gaziulusoy, 2016). However, DfS methodologies present conflicting information about what should be considered to enable sustainable design. For example, cradle-tocradle encourages designers to use waste as food or input for new design processes (Bjørn and Strandesen, 2011) whereas emotional durable design focuses on the longevity of a product (HainesGadd et al., 2018). Additionally, Bakker et al. (2010) discussed designers are not in the position to enforce cradle-to-cradle, and they must find a company which already implements this. Brones et al. (2014) found that although some eco-design principles were being integrated in industry, the term eco-design was rarely employed. Due to the disconnect identified within DfS methodologies and limited evidence that they are currently being actively integrated within industry, researchers focused on uncovering all individual factors of environmental sustainability suggested for implementation during the product design process.

Deutz et al. (2013) investigated eco-design within the UK through interviews, however questions focused on sustainability legislation understanding and whether designers considered general sustainable impact, waste, end of life, materials, pollution, energy, transport, or any additional concerns. There were varied responses to each factor, however researchers did not investigate all identified factors of environmental sustainability. Sustainable production principles have also previously been investigated, interviews with participants focused on the 9 Lowell Centre for Sustainable Production (LCSP) principles (Alayón et al., 2017). Although the results of this study identified some of the factors of environmental sustainability, it investigated these themes from the perspective of environmental managers or production managers opposed to designers. As designers have been identified to have up to $80 \%$ impact on the overall sustainability of the product (Ahmad et al., 2018; Waage, 2007; Yang and Song, 2006) it is important to target and understand this demographic specifically. The identification of the 18 factors as well as the investigation into previous studies have enabled the framing of key questions to explore these themes during the interviews.

\subsection{The typical product design process}

The product design process is described in several ways throughout literature. First, Deutz et al. (2013) categorise the structured design process as design brief, functional requirement, conceptual design, embodiment design, detailed design and consultation. The design process can also be divided into four stages (product planning, conceptual, embodiment and detailed design) (Buchert et al., 2017). The typical design process, as depicted in Figure 1, generally consists of six stages, the 
preparation stage, concept design, embodiment design, detail design, design finalization and process planning and production (Wright, 1998; Chiu and Chu, 2012). The typical design process was important within the study to help frame questions on the management and integration of the identified 18 factors of environmental sustainability as well as in the development of the initial conceptual framework.

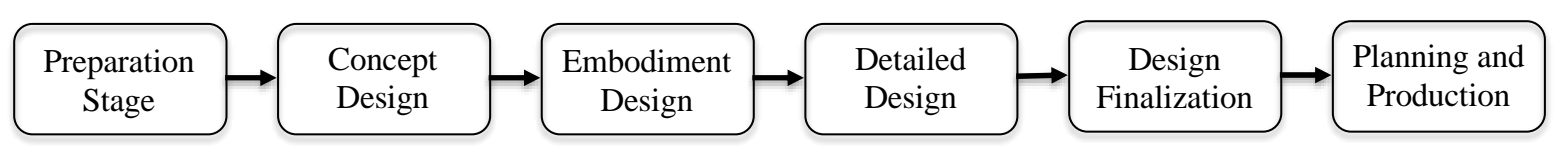

Figure 1. Typical Product Design Process adapted from (Wright, 1998; Chiu and Chu, 2012).

\section{Methodology}

\subsection{Literature Review}

First, a thorough literature review was conducted to provide theoretical background to the study which identified key factors of environmental sustainability, see Table 1. No previous study has investigated all 18 factors from the perspective of the designer in industry, this aided the development of interview questions. Academic Libraries powered by EBSCO, Scopus and Google Scholar were used to conduct the search of literature spanning themes of product design, DfS and environmental sustainability over a 40-year period. This time was selected due to the release of the Brundtland Report (1987). Over 200 papers were initially screened through reading the title of the paper. Following this a more detailed screening was conducted, consisting of reading the abstract and table of contents, this removed around 100 irrelevant studies and papers in other languages. Finally, the papers were read in full to ensure a detailed review and only the most relevant literature was selected for this study, resulting in 41 papers.

Table 1. Factors of Environmental Sustainability

\begin{tabular}{lll}
\hline $\begin{array}{l}\text { Factors of Environmental } \\
\text { Sustainability }\end{array}$ & Brief Definition & Supporting References \\
\hline 6Rs & $\begin{array}{l}\text { Reduce, reuse, recycle, recover } \\
\text { redesign, and remanufacture. }\end{array}$ & $\begin{array}{l}\text { (Metta and Badurdeen, 2013; } \\
\text { Yan and Feng, 2014; Go et al., } \\
\text { 2015) }\end{array}$ \\
\hline $\begin{array}{lll}\text { Global Warming and } \\
\text { Emissions }\end{array}$ & $\begin{array}{l}\text { Greenhouse, ozone depletion, } \\
\text { acidification, and oxidation } \\
\text { potential. }\end{array}$ & $\begin{array}{l}\text { (Gardner and Roseland, 1989; } \\
\text { Rosemarin, 1989; Glavič and } \\
\text { Lukman, 2007) }\end{array}$ \\
\hline Waste & $\begin{array}{l}\text { Waste should be minimised, } \\
\text { including process, packaging, } \\
\text { assembly, disassembly and } \\
\text { defect. }\end{array}$ & $\begin{array}{l}\text { (de Ron, 1998; Stuart et al., } \\
\text { 1999) }\end{array}$ \\
& $\begin{array}{l}\text { Energy use and energy } \\
\text { efficiency. }\end{array}$ & $\begin{array}{l}\text { (de Ron, 1998; Graedel and } \\
\text { Guth, 1990; Tang and Bhamra, } \\
\text { 2008) }\end{array}$ \\
\hline Energy & $\begin{array}{l}\text { Resources which are in a } \\
\text { continuously renewing state. }\end{array}$ & $\begin{array}{l}\text { (Glavič and Lukman, 2007; } \\
\text { Singh et, 2007) }\end{array}$ \\
\hline $\begin{array}{l}\text { Renewable Energy and } \\
\text { Resources }\end{array}$ & &
\end{tabular}




\begin{tabular}{|c|c|c|}
\hline $\begin{array}{l}\text { Material and Resource } \\
\text { Utilization }\end{array}$ & $\begin{array}{l}\text { Minimize the consumption of } \\
\text { resources without reducing the } \\
\text { benefits of the product. }\end{array}$ & $\begin{array}{l}\text { (Ceschin and Gaziulusoy, 2016; } \\
\text { Metta and Badurdeen, 2013) }\end{array}$ \\
\hline Material Selection & Selecting materials. & $\begin{array}{l}\text { (Graedel et al., 1995; Eddy et } \\
\text { al., 2015) }\end{array}$ \\
\hline Process Selection & $\begin{array}{l}\text { Selecting a manufacturing } \\
\text { process. }\end{array}$ & $\begin{array}{l}\text { (Stuart et al., 1999; He et al., } \\
\text { 2019; Zhang et al., 2020) }\end{array}$ \\
\hline Transport and Logistics & $\begin{array}{l}\text { Determining transportation } \\
\text { methods during the product } \\
\text { lifecycle. }\end{array}$ & $\begin{array}{l}\text { (de Ron, 1998; Venkata Rao, } \\
\text { 2009; Singh et al., 2007) }\end{array}$ \\
\hline $\begin{array}{l}\text { Durability and/or } \\
\text { Longevity }\end{array}$ & $\begin{array}{l}\text { Extending product lifetime } \\
\text { whilst remaining the same form } \\
\text { and functionality. }\end{array}$ & $\begin{array}{l}\text { (Zhang et al., 2020; de Ron, } \\
\text { 1998; Vimal et al., 2016; Yan } \\
\text { and Feng, 2014) }\end{array}$ \\
\hline Modularity & $\begin{array}{l}\text { The degree to which a } \\
\text { product's components may be } \\
\text { separated and recombined. }\end{array}$ & $\begin{array}{l}\text { (Hata et al., 2001; Sonego et al., } \\
\text { 2018) }\end{array}$ \\
\hline Eco-Business & $\begin{array}{l}\text { To consider the economic } \\
\text { advantage of sustainability. }\end{array}$ & (Pieroni et al., 2019) \\
\hline $\begin{array}{l}\text { Structural and Functional } \\
\text { Considerations }\end{array}$ & $\begin{array}{l}\text { The adaptation of structural or } \\
\text { functional properties to } \\
\text { improve sustainability. }\end{array}$ & $\begin{array}{l}\text { (Graedel et al., 1995; Kuo and } \\
\text { Wang, 2019; Eddy et al., 2013) }\end{array}$ \\
\hline Resource Depletion & $\begin{array}{l}\text { The consumption of resources } \\
\text { per unit production. }\end{array}$ & $\begin{array}{l}\text { (Metta and Badurdeen, 2013; } \\
\text { Go et al., 2015; Hapuwatte and } \\
\text { Jawahir, 2019) }\end{array}$ \\
\hline User Behaviour & $\begin{array}{l}\text { To understand how consumer } \\
\text { behaviour creates a demand } \\
\text { for sustainable products and } \\
\text { how their behaviour impacts } \\
\text { sustainability. }\end{array}$ & $\begin{array}{l}\text { (Venkata Rao, 2005; Chen, } \\
\text { 2001; Tang and Bhamra, 2008) }\end{array}$ \\
\hline $\begin{array}{l}\text { Toxicity and Hazardous } \\
\text { Production }\end{array}$ & $\begin{array}{l}\text { The by-products of production } \\
\text { which can cause harm. }\end{array}$ & $\begin{array}{l}\text { (Chen, 2001; Overby, 1991; } \\
\text { Rosemarin, 1989) }\end{array}$ \\
\hline $\begin{array}{l}\text { Government } \\
\text { Regulations/Laws/ } \\
\text { Guidelines }\end{array}$ & $\begin{array}{l}\text { Laws which have been } \\
\text { introduced by the government } \\
\text { to encourage sustainability. }\end{array}$ & $\begin{array}{l}\text { (Wang et al., 2020; de Ron, } \\
\text { 1998) }\end{array}$ \\
\hline Packaging & $\begin{array}{l}\text { Considering sustainability } \\
\text { factors during packaging } \\
\text { design. }\end{array}$ & $\begin{array}{l}\text { (Chan et al., 2014; Graedel et } \\
\text { al., 1995) }\end{array}$ \\
\hline
\end{tabular}

\subsection{Semi-Structured Interviews}

Following the literature review, in-depth semi-structured interviews were conducted with 12 industry professionals. Questions concentrated on the 18 factors of environmental sustainability, determining whether the participant considered each factor, when during the design process they considered them, whether they employed any DfS methodologies, if they used any tools and 
whether there were any stakeholders involved in the design process. Each interview lasted between 40 and 70 minutes, this enabled the participant to answer all questions as well as for the researchers to explore and clarify these answers for further information. All interviews were recorded and transcribed. This enabled coding of key and common themes, using NVivo software.

To explore these themes successfully, participants were purposefully selected using two main selection criteria: (1) the participant must have experience working within the product design industry and (2) the participant must have experience in environmental sustainability. Researchers used two reach-out methods to identify potential candidates for the study. The first method was to reach-out to businesses with a strong sustainability background, this included investigating their current products for sustainability features as well as looking at their company ethos for sustainability values, to ask members of design teams to participate. The second method was completed via contacting designers directly via LinkedIn, prior to reaching out researchers viewed their public profile for evidence of product design and environmental sustainability experience. These methods resulted in 12 participants, with varying levels of experience. See Table 2 for a summary of participants.

Table 2. Participant Profiles

\begin{tabular}{|c|c|c|}
\hline Participant ID & Occupation & Experience \\
\hline ID-1 & Product Designer & $\begin{array}{l}3 \text { Years in Industry, Completed } \\
\text { a master's degree in } \\
\text { Sustainability. }\end{array}$ \\
\hline ID-2 & $\begin{array}{l}\text { Product Designer and } \\
\text { Sustainability Consultant }\end{array}$ & $\begin{array}{l}9 \text { Years in Industry, Founder of } \\
\text { a sustainable product-based } \\
\text { company. }\end{array}$ \\
\hline ID-3 & $\begin{array}{l}\text { Designer of Sustainability in the } \\
\text { Built Environment }\end{array}$ & $\begin{array}{l}8 \text { Years in Industry, Lecturer for } \\
9 \text { Years, Researcher for } 7 \text { Years. }\end{array}$ \\
\hline ID-4 & $\begin{array}{l}\text { Product Designer and } \\
\text { Developer }\end{array}$ & $\begin{array}{l}2 \text { Years in industry, } 1 \text { year for a } \\
\text { sustainability product-based } \\
\text { company. }\end{array}$ \\
\hline ID-5 & Sustainable Designer & $\begin{array}{l}10 \text { Years in Industry, Completed } \\
\text { a master's degree in Creative } \\
\text { Sustainability. }\end{array}$ \\
\hline ID-6 & Sustainable Designer & $\begin{array}{l}1 \text { Year in Industry, Completed a } \\
\text { bachelor's degree in } \\
\text { Sustainable Product Design. }\end{array}$ \\
\hline ID-7 & Sustainable Designer & $\begin{array}{l}4 \text { Years in Industry, } 1 \text { Year as a } \\
\text { researcher focused on bio- } \\
\text { based fabrics. }\end{array}$ \\
\hline ID-8 & Sustainable Designer & $\begin{array}{l}7 \text { Years in Industry, } 3 \text { Years } \\
\text { employed as a Sustainable } \\
\text { Designer, Completed Business } \\
\text { Sustainability Management } \\
\text { Course. }\end{array}$ \\
\hline
\end{tabular}




\begin{tabular}{|c|c|c|}
\hline ID-9 & $\begin{array}{l}\text { Sustainable Designer and } \\
\text { Researcher }\end{array}$ & $\begin{array}{l}11 \text { Years in Industry, } 5 \text { Years } \\
\text { employed as a Sustainable } \\
\text { Designer, Completed a master's } \\
\text { degree in Eco-design and Eco- } \\
\text { innovation. }\end{array}$ \\
\hline ID-10 & $\begin{array}{l}\text { Product Developer and } \\
\text { Sustainability Consultant }\end{array}$ & $\begin{array}{l}14 \text { Years in Industry, } 2 \text { Years } \\
\text { employed as a Sustainability } \\
\text { Consultant, Completed } \\
\text { Business Sustainability } \\
\text { Management Course. }\end{array}$ \\
\hline ID-11 & $\begin{array}{l}\text { Product Designer and } \\
\text { Developer }\end{array}$ & 8 Years in Industry. \\
\hline ID-12 & Designer & $\begin{array}{l}15 \text { Years in Industry, Studio } \\
\text { Lead at a school of design, } \\
\text { Completed a Sustainability } \\
\text { Education Course, Member of a } \\
\text { collective called the Climate } \\
\text { Designers. }\end{array}$ \\
\hline
\end{tabular}

\section{Results}

User behaviour, energy, material and resource utilization and structural and functional considerations were all factors which were considered but predominately as general design criteria with some sustainable benefits. Packaging was identified to be a separate process by the majority of participants.

Government guidelines, eco-business toxicity and process selection were mostly identified to be out of the designer's control. ID-6 stated that "process selection is harder to control" and that a "level of trust" is required between the designer and manufacture to ensure that they are being responsible, this was supported by ID-8. Business managers and CEOs were also identified as having the control and responsibility over these factors and ID-10 suggested that they should encourage their design team to design for sustainability opposed to saving cost and that a "businesses need to make a shift" to enable further sustainable development.

When discussing management and assessment methods for environmental sustainability during the product design process, many participants had "no measuring method or tool" and often just feel "confident in the methods" (ID-6) which they have employed. However, ID-8, ID-9 and ID-10 all currently or have previously employed the LCA method but ID-8 found them "long and not very accurate" and ID-9 felt that "good access to material databases" were essential for designers to be successful. 


\subsection{Product Design Environmental Sustainability Framework}

To aid in the implementation of environmental sustainability during the design process, the data collected and analysed from the semi-structured interviews has enabled the development of an initial conceptual framework. This framework illustrates the current status of environmental sustainability integration within the product design process. The framework follows the typical product design process, shown previously in Figure 1. Throughout the interviews, participants indicated that although some of the factors discussed had environmental sustainability benefits, they did not view them as primarily environmental sustainability factors. Factors were primarily categorised by participants as environmental sustainability factors; however some were categorised as design criteria with environmental sustainability, stakeholder responsibility opposed to designer responsibility and others were part of a separate process from the design process. Table 3 indicates these 4 categories.

Table 3. Categorisation of the 18 environmental sustainability factors

\begin{tabular}{llll}
\hline $\begin{array}{l}\text { Environmental } \\
\text { Sustainability }\end{array}$ & Design Criteria & $\begin{array}{l}\text { Stakeholder } \\
\text { Responsibility }\end{array}$ & Separate Process \\
\hline - Material & - User behaviour & - Government & - Packaging \\
selection & - Energy & regulations/laws/ & \\
- 6Rs & - Material and & guidelines & \\
- Renewable & resource utilization & - Toxicity and & \\
material and & - Structural and & hazardous \\
resources & functional & production & \\
- Resource & considerations & - Process selection & \\
depletion & & - Eco-business & \\
- Transport and & & & \\
Logistics & & \\
- Durability & & \\
- Modularity & & \\
- Global Warming & & \\
and Emissions & & \\
- Waste & & \\
\hline
\end{tabular}

The framework, shown in Figure 2, integrates the environmental sustainability and design criteria into the typical product design process as well as any tools or stakeholders. The placement of each factor aligns with the information received through the semi-structured interviews. 


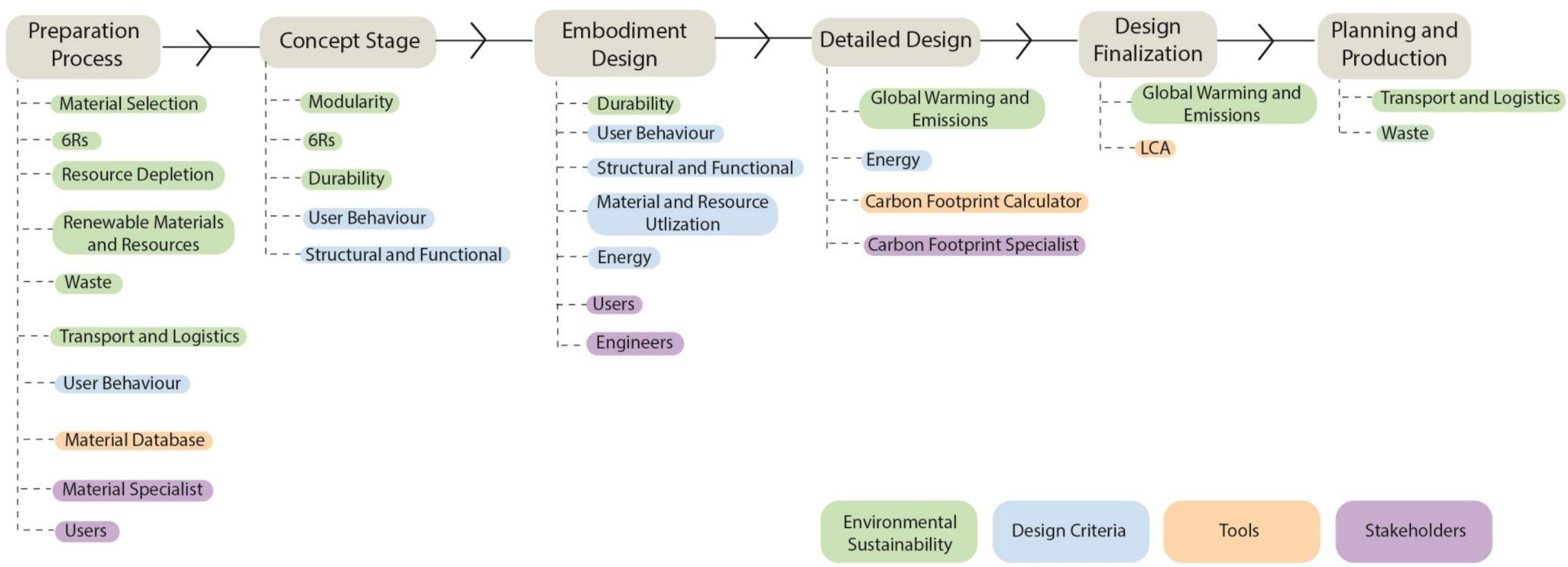

Figure 2. Initial Conceptual Environmental Sustainability Framework 


\section{Discussions}

From the two-stage methodology it is apparent that environmental sustainability is an extensive and complex topic within product design. The identification of 18 factors reinforces product designer's responsibility during NPD. The semi-structured interviews provided insight into the current status of environmental sustainability in the product design process, as well as the general understanding of environmental sustainability of practicing designers. Out of the 18 factors, participants were confident in the factors that focused on their design principles such as material selection and user behaviour opposed to factors like government regulations. This identified some areas of limited knowledge from designers, it is also unclear whether companies are equipped to handle government regulations in relation to environmentally sustainable product design. There are potential implications for this gap in expertise, as the product design stage has been identified as having up to $80 \%$ impact of the sustainability of a product (Ahmad et al., 2018; Waage, 2007; Yang and Song, 2006), it is therefore important that product designers are effectively educated in environmental sustainability and how to integrate this into their design process. Businesses and governments also have a responsibility to equip and inform design teams on changes on regulations that their products must adhere to so that they can integrated into the product design stage. Additionally, participants didn't necessarily agree with literatures conclusion that all factors were (a) environmental sustainability focused and (b) their responsibility. Further investigation is required to determine what is the designer's responsibility and how to ensure all stakeholders of the NPD process enable successful implementation of environmental sustainability. Furthermore, this study specifically targeted designers with environmental sustainability experience. This could suggest that other product designers without this expertise are less knowledgeable or experienced in implementing environmental sustainability and may need further support in this area.

To address the research question of this study, an initial conceptual framework was developed to illustrate the current status on environmental sustainability in the product design process during NPD. Further investigation is needed to develop this framework on variables such as stakeholder integration, management, assessment and whether the framework needs to be adaptable to suit various product types. As the majority of participants did not have a method of assessing or managing environmentally sustainable NPD, it is suggested that future research aims to address this.

\subsection{Suggestions for Future Research}

Three themes were identified for future research: design education, government responsibility and circular economy. It was clear from the semi-structured interviews that participants that had taken sustainability-specific courses were more confident and knowledgeable when answering the questions, but they also identified that this shouldn't have to be an additional course and should be integrated into the foundations of design education. Research is required to investigate the current status of design education and how it is equipping future designers with the skills of sustainability. Government regulations was a factor predominately identified by participants as not their responsibility, but participants also discussed that they felt legislations should be stricter to ensure sustainable NPD, further clarity and development is required for sustainability-focused laws. Finally, many participants discussed circular economy during their interviews, as a methodology which they consider aiding environmental sustainability during the design process. This has identified a key concept which should be investigated further to aid sustainable NPD. 


\section{Conclusions}

Literature and industry both acknowledge that environmental sustainability is a key issue and are actively trying to develop solutions to aid it during the product design process. Data collection and analysis has enabled a review of the current status of environmental sustainability integration during the product design process. An initial conceptual framework has been developed to illustrate the placement of environmental sustainability factors during the product design process concluded from the findings of the data analysis. The study has also suggested areas of improvement to further develop environmental sustainability during the design process. 


\section{References}

Ahmad, S., Wong, K. Y., Tseng, M. L., \& Wong, W. P. (2018). Sustainable product design and development: A review of tools, applications and research prospects. Resources, Conservation and Recycling, 132, 49-61.

Alayón, C., Säfsten, K., \& Johansson, G. (2017). Conceptual sustainable production principles in practice: do they reflect what companies do? Journal of cleaner production, 141, 693-701.

Bakker, C., Wever, R., Teoh, C., \& De Clercq, S. (2010). Designing cradle-to-cradle products: a reality check. International Journal of Sustainable Engineering, 3(1), 2-8.

Bjørn, A., \& Strandesen, M. (2011). The Cradle to Cradle concept-is it always sustainable? Paper presented at the The Life Cycle Management (LCM) conference: Towards Life Cycle Sustainability Management.

Brones, F., de Carvalho, M. M., \& de Senzi Zancul, E. (2014). Ecodesign in project management: a missing link for the integration of sustainability in product development? Journal of cleaner production, 80, 106-118.

Brundtland, G. H., Khalid, M., Agnelli, S., Al-Athel, S., \& Chidzero, B. (1987). Our common future. New York, 8.

Buchert, T., Halstenberg, F. A., Bonvoisin, J., Lindow, K., \& Stark, R. (2017). Target-driven selection and scheduling of methods for sustainable product development. Journal of cleaner production, $161,403-421$.

Ceschin, F., \& Gaziulusoy, I. (2016). Evolution of design for sustainability: From product design to design for system innovations and transitions. Design studies, 47, 118-163.

Chan, H. K., Wang, X., \& Raffoni, A. (2014). An integrated approach for green design: Life-cycle, fuzzy AHP and environmental management accounting. The British Accounting Review, 46(4), 344-360.

Chen, C. (2001). Design for the environment: A quality-based model for green product development. Management Science, 47(2), 250-263.

Chiu, M.-C., \& Chu, C.-H. (2012). Review of sustainable product design from life cycle perspectives. International Journal of Precision Engineering and Manufacturing, 13(7), 1259-1272.

Clark, G., Kosoris, J., Hong, L. N., \& Crul, M. (2009). Design for sustainability: current trends in sustainable product design and development. Sustainability, 1(3), 409-424.

De Ron, A. J. (1998). Sustainable production: the ultimate result of a continuous improvement. International Journal of Production Economics, 56, 99-110.

Deutz, P., McGuire, M., \& Neighbour, G. (2013). Eco-design practice in the context of a structured design process: an interdisciplinary empirical study of UK manufacturers. Journal of cleaner production, 39, 117-128.

Eddy, D. C., Krishnamurty, S., Grosse, I. R., Wileden, J. C., \& Lewis, K. E. (2015). A predictive modelling-based material selection method for sustainable product design. Journal of Engineering Design, 26(10-12), 365-390.

Gardner, J., \& Roseland, M. (1989). Thinking Globally and Acting Locally Part I: Thinking Globally: The Role of Social Equity in Sustainable Development. Alternatives, 26-34.

Glavič, P., \& Lukman, R. (2007). Review of sustainability terms and their definitions. Journal of cleaner production, 15(18), 1875-1885.

Go, T. F., Wahab, D. A., \& Hishamuddin, H. (2015). Multiple generation life-cycles for product sustainability: the way forward. Journal of cleaner production, 95, 16-29.

Graedel, T. E., Comrie, P. R., \& Sekutowski, J. C. (1995). Green product design. AT\&T Technical Journal, 74(6), 17-25. 
Graedel, T. E., \& Guth, L. A. (1990). The impact of environmental issues on materials and processes. AT\&T Technical Journal, 69(6), 129-140.

Haines-Gadd, M., Chapman, J., Lloyd, P., Mason, J., \& Aliakseyeu, D. (2018). Emotional durability design nine-A tool for product longevity. Sustainability, 10(6), 1948.

Hapuwatte, B. M., \& Jawahir, I. S. (2019). A total life cycle approach for developing predictive design methodologies to optimize product performance. Procedia Manufacturing, 33, 11-18.

Hata, T., Kato, S., \& Kimura, F. (2001). Design of product modularity for life cycle management. Paper presented at the Proceedings second international symposium on environmentally conscious design and inverse manufacturing.

He, B., Luo, T., \& Huang, S. (2019). Product sustainability assessment for product life cycle. Journal of cleaner production, 206, 238-250.

Kuo, T. C., \& Wang, C.-J. (2019). Integrating robust design criteria and axiomatic design principles to support sustainable product development. International Journal of Precision Engineering and Manufacturing-Green Technology, 6(3), 549-557.

Metta, H., \& Badurdeen, F. (2012). Integrating sustainable product and supply chain design: modeling issues and challenges. IEEE transactions on engineering management, 60(2), 438-446.

Overby, C. M. (1991). Sustainability through Design for the Entire Life Cycle. Paper presented at the Proceedings of the 1991 International Symposium on Technology and Society-ISTAS91.

Pieroni, M. P., McAloone, T. C., \& Pigosso, D. C. (2019). Business model innovation for circular economy and sustainability: A review of approaches. Journal of cleaner production, 215, 198-216.

Rosemarin, A. (1989). Global change, sustainable development and the dangers of information overkill. Ambio. Stockholm, 18(6), 307.

Singh, S., Goodyer, J., \& Popplewell, K. (2007). Integrated environmental process planning for the design and manufacture of automotive components. International Journal of Production Research, 45(18-19), 4189-4205.

Sonego, M., Echeveste, M. E. S., \& Debarba, H. G. (2018). The role of modularity in sustainable design: A systematic review. Journal of cleaner production, 176, 196-209.

Stuart, J. A., Ammons, J. C., \& Turbini, L. J. (1999). A product and process selection model with multidisciplinary environmental considerations. Operations Research, 47(2), 221-234.

Tang, T., \& Bhamra, T. (2008). Changing energy consumption behaviour through sustainable product design. Paper presented at the DS 48: Proceedings DESIGN 2008, the 10th International Design Conference, Dubrovnik, Croatia.

Venkata Rao, R. (2009). An improved compromise ranking method for evaluation of environmentally conscious manufacturing programs. International Journal of Production Research, 47(16), 43994412.

Vimal, K., Vinodh, S., Brajesh, P., \& Muralidharan, R. (2016). Rapid prototyping process selection using multi criteria decision making considering environmental criteria and its decision support system. Rapid Prototyping Journal.

Waage, S. A. (2007). Re-considering product design: a practical "road-map" for integration of sustainability issues. Journal of cleaner production, 15(7), 638-649.

Wang, M., Zhang, Z., Li, K., Zhang, Z., Sheng, Y., \& Liu, S. (2020). Research on key technologies of fault diagnosis and early warning for high-end equipment based on intelligent manufacturing and Internet of Things. The International Journal of Advanced Manufacturing Technology, 107(3), 1039-1048.

Wright, I. C. (1998). Design methods in engineering and product design: McGraw-Hill.

Yan, J., \& Feng, C. (2014). Sustainable design-oriented product modularity combined with 6R concept: a case study of rotor laboratory bench. Clean Technologies and Environmental Policy, 16(1), 95-109. 
Yang, Q., \& Song, B. (2006). Eco-design for product lifecycle sustainability. Paper presented at the 2006 4th IEEE International Conference on Industrial Informatics.

Zhang, X., Zhang, L., Fung, K. Y., Bakshi, B. R., \& Ng, K. M. (2020). Sustainable product design: A lifecycle approach. Chemical Engineering Science, 217, 115508. 